\section{Above-grade Planting with Organic Matter Improves Post-transplant Growth of Two Native Shrub Species}

\author{
Julie Guckenberger Price ${ }^{1,3,4}$, Amy N. Wright ${ }^{1}$, Robert S. Boyd ${ }^{2}$, \\ and Kenneth M. Tilt ${ }^{1}$
}

AdDitional Index wORDs. landscape, establishment, Morella cerifera, Myrica cerifera, wax myrtle, Kalmia latifolia, mountain laurel

SUMMARY. Planting shrubs above-grade with organic matter has shown potential for improving landscape establishment. To further investigate this technique, wax myrtle [Morella cerifera (syn. Myrica cerifera)] (3 gal) and mountain laurel (Kalmia latifolia 'Olympic Wedding') (5 gal) were planted on 30 Oct. 2006 (fall planting) and 12 Apr. 2007 (spring planting) in the ground in a shade house in Auburn, AL. At each planting date, plants of each species were assigned one of four treatments. Three of four treatments used a modified above-grade planting technique in which shrubs were planted such that the top 3 inches of the root ball remained above soil grade. Organic matter, either pine bark (PB), peat (PT), or cotton gin compost (CGC), was applied around the above-grade portion of the root ball, tapering down from the top of the root ball to the ground. In the fourth treatment, plants were planted at-grade with no organic matter (NOM). In general, both species had higher shoot dry weight (SDW) and root spread (RS) when planted in the fall than when planted in spring. Among all treatments, plants also typically had larger RS when planted above-grade with PB or PT. For easy-to-transplant species (such as wax myrtle) and especially for difficult-to-transplant species like mountain laurel, fall planting using this modified above-grade planting technique with PB or PT may improve post-transplant root growth and speed establishment in the first growing season.

$\mathrm{N}$ ewly transplanted trees and shrubs in urban areas frequently encounter compacted soils with disturbed horizons, competition for space with underground infrastructure, pollution, excessive heat, high foot traffic, and are often neglected in terms of irrigation and fertilization. Root growth into the surrounding soil is vital to plant survival and establishment. To make the plants attractive for purchase, nursery-grown plants are often heavily irrigated and fertilized to encourage rapid shoot growth. Once transplanted, it may be difficult for the plant to compensate for evapotranspiration from these abnormally large canopies using only the resources available in the root ball, whereas at the same time allocating energy to root

We thank Moore and Davis Nursery (Shorter, AL) and Historyland Nursery (Warsaw, VA) for plant material. Also, thanks to Peng Zeng, Department of Statistics, Auburn University, Auburn, AL, for statistical counsel.

${ }^{1}$ Department of Horticulture, Auburn University, 101 Funchess Hall, Auburn, AL 36849

${ }^{2}$ Department Of Biological Sciences, Auburn University, 101 Rouse Life Science Building, Auburn, AL 36849

${ }^{3}$ Current address: Department of Biology, University of Alabama at Birmingham, 1530 3rd Avenue S, Campbell Hall 464, Birmingham, AL 35294-1170

${ }^{4}$ Corresponding author. E-mail: juliegp@uab.edu. growth. In such difficult growing situations, many of these plants do not survive (Day et al., 1995). In both horticulture and urban forestry, most research on plant performance in constructed urban landscapes is performed on trees. Although this is important, research on successful transplanting of the woody shrubs that constitute the backbone of many landscapes is also imperative.

Studies on planting above-grade have proven it to be a successful technique, both with trees (Arnold et al., 2005 ) and woody shrubs (Wright et al., 2007). Wright et al. (2007) described a modified above-grade planting technique in which the upper portion of the root ball remained above the soil surface, and PB was mounded around the above-grade portion of the root ball, tapering from the top of the root ball down to the surrounding soil grade. More root growth occurred in shrubs of the very difficult to transplant species mountain laurel planted with this technique than in those planted at-grade with PB amended backfill or at-grade with NOM (Wright et al., 2007).

The technique of Wright et al. (2007) attempts to simulate the organic litter layer found in natural environments, encouraging the initial proliferation of roots in this layer followed by proliferation in the upper soil horizons. As recommendations for using native plant species increase (Southeast Exotic Pest Plants Council, n.d.), it is possible that this planting technique could be used to successfully establish native shrubs in a variety of landscapes. The objective of this study was to determine the effect of planting technique, organic matter selection with above-grade planting, and planting season on post-transplant growth of two native landscape shrubs selected for their reportedly different landscape establishment success rates (Dirr, 1998).

\section{Materials and methods}

On 30 Oct. 2006 (hereafter referred to as fall planting) and $12 \mathrm{Apr}$. 2007 (hereafter referred to as spring planting), 24 plants each of 3-gal wax myrtle (Moore and Davis Nursery, Shorter, AL) and 5-gal mountain laurel (Historyland Nursery, Warsaw, VA) were planted in the ground in six rows (blocks) under a $50 \times 30$-ft shade house covered with shade cloth with $47 \%$ transmission. The shade house was located in the field research plots on the campus of Auburn University, Auburn, AL. The soil under the shade house was Marvyn sandy loam, which is a typical pedon of the Marvyn Series (fine-loamy, kaolinitic, thermic typic Kanhapludults), which are deep, well-drained,

\begin{tabular}{llll}
\hline $\begin{array}{l}\text { Units } \\
\text { To convert U.S. to SI, } \\
\text { multiply by }\end{array}$ & U.S. unit & SI unit & $\begin{array}{l}\text { To convert SI to U.S., } \\
\text { multiply by }\end{array}$ \\
\hline 0.3048 & $\mathrm{ft}$ & $\mathrm{m}$ & 3.2808 \\
0.0929 & $\mathrm{ft}^{2}$ & $\mathrm{~m}^{2}$ & 10.7639 \\
3.7854 & gal & $\mathrm{L}$ & 0.2642 \\
2.54 & inch $(\mathrm{es})$ & $\mathrm{cm}$ & 0.3937 \\
0.4536 & $\mathrm{lb}$ & $\mathrm{kg}$ & 2.2046 \\
28.3495 & $\mathrm{oz}$ & $\mathrm{g}$ & 0.0353 \\
1.7300 & $\mathrm{oz} / \mathrm{inch}^{3}$ & $\mathrm{~g} \cdot \mathrm{cm}^{-3}$ & 0.5780 \\
1 & $\mathrm{ppm}$ & $\mathrm{mg} \cdot \mathrm{L}^{-1}$ & 1 \\
$\left({ }^{\circ} \mathrm{F}-32\right) \div 1.8$ & ${ }^{\circ} \mathrm{F}$ & ${ }^{\circ} \mathrm{C}$ & $\left(1.8 \times{ }^{\circ} \mathrm{C}\right)+32$
\end{tabular}


moderately permeable soils formed in loamy marine sediments on Coastal Plain uplands (U.S. Department of Agriculture, 1997) with field capacity ranging from $25 \%$ to $50 \%$ and available water ranging from $7 \%$ to $8 \%$ based on soil tests (Auburn University Soil Testing Laboratory, Auburn, AL). The upper 3 to 4 inches of soil were tilled using a rototiller, and planting holes were hand dug with a shovel twice the diameter of the original root ball. Sides of the planting hole were disturbed (not smooth). Rootballs were kept intact and not disturbed before planting. All plants were acquired at the same time, and spring-planted shrubs overwintered on a nursery pad with daily irrigation and winter cover when needed. Each block in the shade house contained eight plants of each species, four planted in fall and four planted in spring, for a total of 96 plants in the experiment. Within each block, the planting location of each plant was randomly assigned. At each planting, the four plants of each species in a row were randomly assigned one of four planting treatments. Three of four treatments used a modified above-grade planting technique in which plants were planted such that the top 3 inches of the root ball remained above the surface of the ground, using native soil as backfill for the below-grade portion of the root ball. Organic matter, either PB, PT, or CGC, was applied around and in contact with the above-grade portion of the root ball, tapering down from the top of the root ball to the ground at a distance of 12 inches from the stem. Also, 0.5 inch of organic matter was applied on the top of the root ball. In the fourth treatment, plants were planted at-grade with NOM. Pine bark was fresh cut, chipped, and supplied by Pineywoods Mulch Co. (Alexander City, AL) from trees grown in Roanoke, $\mathrm{AL}$, and Cassco (Montgomery, AL) supplied Canadian PT. Cotton gin compost was obtained from cotton gin trash produced by Milstead Farm Group (Shorter, AL) and composted at E.V.Smith Research Center, also in Shorter. Each plant was fertilized at planting with $95.3 \mathrm{~g}$ of $18 \mathrm{~N}-2.6 \mathrm{P}-$ 9.9K encapsulated slow-release fertilizer (12 month, Polyon $®$; Pursell Industries, Sylacauga, AL) as a surface application within 12 inches of the stem. A 3-inch layer of pine straw [longleaf pine needles (Pinus palustris)] was applied on the ground between plants and rows, including on top of the soil backfill or organic matter in all treatments, to simulate a typical landscape scenario with pine straw mulch.

Plant growth indices (GI) [ height + widest width + width perpendicular to widest width $) \div 3$ ] of all planted shrubs were taken at both planting dates. Three additional (nonplanted) plants of each species were harvested for leaf area (LA) [measured using a LA meter (LI-3100; LI-COR BioSciences, Lincoln, NE)] and SDW (shoots cut from the root ball and dried for $48 \mathrm{~h}$ at $66^{\circ} \mathrm{C}$ ) at both planting dates. From these nonplanted shrubs of each species, leaf tissue samples were taken from the most recently matured leaves for tissue nutrient analysis (Auburn University Soil Testing Laboratory) before LA and SDW harvest. Also, at planting in Spring 2007, recently matured leaf tissue samples were collected for tissue nutrient analysis from three plants of each treatment of shrubs planted in Fall 2006.

Three rain gauges were installed at different locations in the shade house, and precipitation and irrigation events (frequency and volume) were recorded throughout the experiment. To ensure no plants experience drought, all plants were irrigated with 1 inch of water from overhead irrigation (number 4 Nozzle mini-Wobbler ${ }^{\circledR}$; Senninger Irrigation, Clermont, FL) when average volumetric water content in any treatment fell below 10\%. Percent moisture was measured weekly using a $\mathrm{TH}_{2} \mathrm{O}$ Soil Moisture Meter (Delta-T Devices; Cambridge, England) inserted into the organic matter (above-grade planting) or soil (at-grade planting) around each root ball, $\approx 8$ inches from the stem. Physical properties of each organic matter type were determined using the North Carolina State University Porometer $^{\mathrm{TM}}$ (Fonteno et al., 1981), and chemical properties of substrates and soil were determined from saturated extracts at the Auburn University Soil Testing Laboratory.

The experiment was ended 18 Sept. 2007. Final GI were recorded, and canopies were rated visually from 0 to 5 , where $0=$ no live tissue, $1=1 \%$ to $25 \%$ live tissue, $2=26 \%$ to $50 \%$ live tissue, $3=51 \%$ to $75 \%$ live tissue, $4=76 \%$ to $100 \%$ live tissue but visible stem dieback or leaf spot, and $5=$ $100 \%$ live tissue and no visible symptoms of disease or drought. Plant canopies were cut from the root ball, dried for $48 \mathrm{~h}$ at $66^{\circ} \mathrm{C}$, and weighed to determine SDW, and from these oven-dried samples a final foliar (no stems) tissue nutrient analysis was performed on recently matured leaves of three plants from each species within each treatment and planting season. Plant root balls were excavated by inserting a shovel into the soil 12 inches from the stem and carefully lifting the root system from the surrounding soil to determine the extent of root growth beyond the original root ball. Root spread [(widest diameter + diameter perpendicular to widest diameter $\div 2]$ within this 12 -inch diameter was recorded for all plants.

Within each species, treatments were in a factorial combination of planting season and planting treatment arranged in a randomized complete block design with six blocks (rows). Each of the six blocks contained one plant of each species subjected to each planting treatment within each planting season. Data were analyzed using general linear models (GLM) procedures to determine main effects and interactions, and mean separations were performed using least significant difference at $\alpha=$ 0.05 (SAS version 9.1; SAS Institute, Cary, NC). Growth and survival data were analyzed separately by species.

\section{Results}

WAX MYRTLE. Survival rate of shrubs was $100 \%$. While initial GI of wax myrtle designated for spring planting $(72.8 \mathrm{~cm})$ was higher at planting than those of fall-planted shrubs $[61.8 \mathrm{~cm}(P=0.0064)]$, by the time of spring planting, fall-planted shrubs had outgrown those designated for spring planting which were overwintered in their containers $(P=0.0234)$. Final GI was higher for shrubs planted in fall than for those planted in the spring $(P<0.0001)$ and fall-planted shrubs were $\approx 45 \%$ larger than springplanted shrubs. There were no differences among treatments within planting season (Table 1A). Although SDW at planting was higher $(P<$ 0.0001 ) for plants planted in Spring $2007(0.17 \mathrm{~kg})$ than for those planted in Fall $2006(0.12 \mathrm{~kg})$, by experiment termination in Fall 2007, shrubs planted the previous fall had higher SDW than those planted in spring $(P<0.0001)$ (Table 1A). LA was similar at planting for spring-planted and fall-planted shrubs (18.4 and 
Table 1. Effect of planting substrate and season on growth index (GI), final visual rating, shoot dry weight (SDW), and root spread (RS) of wax myrtle (A) and mountain laurel (B) planted 30 Oct. 2006 (Fall) and 12 Apr. 2007 (Spring). Plants were harvested 18 Sept. 2007.

\begin{tabular}{|c|c|c|c|c|c|}
\hline \multirow{3}{*}{$\begin{array}{l}\text { A. Wax myrtle } \\
\text { Substrate or soil }\end{array}$} & \multicolumn{5}{|c|}{ Fall-planted } \\
\hline & \multicolumn{2}{|c|}{ GI $(\mathrm{cm})^{y}$} & \multirow[b]{2}{*}{$\begin{array}{c}\text { Final } \\
\text { SDW }(\mathrm{kg})^{x}\end{array}$} & \multirow{2}{*}{$\begin{array}{l}\text { Final visual } \\
\text { rating } \\
(1-5 \text { scale })^{w}\end{array}$} & \multirow[b]{2}{*}{$\begin{array}{c}\text { Final } \\
\text { RS }(\mathrm{cm})\end{array}$} \\
\hline & $\begin{array}{l}\text { Spring } \\
2007\end{array}$ & Final & & & \\
\hline Pine bark $(\mathrm{PB})$ & $84 \mathrm{a}^{\mathrm{u}}$ & $183 a$ & $1.89 \mathrm{a}$ & 5 & $47 \mathrm{a}$ \\
\hline Peat (PT) & $81 \mathrm{a}$ & $173 a$ & $1.87 \mathrm{a}$ & 5 & $52 \mathrm{a}$ \\
\hline $\begin{array}{l}\text { Cotton gin compost } \\
\text { (CGC) }\end{array}$ & $78 \mathrm{a}$ & $171 \mathrm{a}$ & $1.60 \mathrm{a}$ & 5 & $35 \mathrm{~b}$ \\
\hline $\begin{array}{l}\text { Soil, no organic } \\
\text { matter (NOM) }\end{array}$ & $80 \mathrm{a}$ & $171 \mathrm{a}$ & $1.69 \mathrm{a}$ & 5 & $34 \mathrm{~b}$ \\
\hline
\end{tabular}

\begin{tabular}{|c|c|c|c|c|c|}
\hline & \multicolumn{5}{|c|}{ Spring-planted } \\
\hline PB & - & $125 \mathrm{a}$ & $0.69 \mathrm{a}^{1}$ & 5 & $47 \mathrm{a}$ \\
\hline PT & - & $121 \mathrm{a}$ & $0.73 \mathrm{a}$ & 5 & $53 \mathrm{a}$ \\
\hline CGC & - & $119 \mathrm{a}$ & $0.61 \mathrm{a}$ & 5 & $28 \mathrm{c}$ \\
\hline NOM & - & $119 \mathrm{a}$ & $0.68 \mathrm{a}$ & 5 & $39 \mathrm{~b}$ \\
\hline \multirow[b]{2}{*}{ B. Mountain laurel } & \multicolumn{5}{|c|}{ Fall-planted } \\
\hline & \multicolumn{2}{|c|}{ GI $(\mathrm{cm})$} & \multirow{2}{*}{\multicolumn{2}{|c|}{$\begin{array}{c}\text { Final visual } \\
\text { rating } \\
(1-5 \text { scale })\end{array}$}} & \multirow[b]{2}{*}{$\begin{array}{c}\text { Final } \\
\mathrm{RS}(\mathrm{cm})\end{array}$} \\
\hline Substrate or soil & $\begin{array}{c}\text { Spring } \\
2007\end{array}$ & Final & & & \\
\hline $\mathrm{PB}$ & $60 \mathrm{a}$ & $75 \mathrm{a}$ & $0.50 \mathrm{a}$ & 5 & $40 \mathrm{a}$ \\
\hline PT & $56 \mathrm{ab}$ & $76 \mathrm{a}$ & $0.42 \mathrm{ab}$ & 4 & $40 \mathrm{a}$ \\
\hline CGC & $58 \mathrm{ab}$ & $71 \mathrm{a}$ & $0.35 \mathrm{~b}$ & 4 & $29 \mathrm{~b}$ \\
\hline NOM & $55 \mathrm{~b}$ & $70 \mathrm{a}$ & $0.36 \mathrm{~b}$ & 4 & $28 \mathrm{~b}$ \\
\hline
\end{tabular}

\begin{tabular}{llllll} 
& & \multicolumn{5}{c}{ Spring-planted } \\
PB & - & $65 \mathrm{a}$ & $0.36 \mathrm{a}$ & 4 & $38 \mathrm{a}$ \\
PT & - & $63 \mathrm{a}$ & $0.25 \mathrm{a}$ & 3 & $32 \mathrm{~b}$ \\
CGC & - & $40 \mathrm{~b}$ & $0.10 \mathrm{~b}$ & 1 & $27 \mathrm{c}$ \\
NOM & - & $71 \mathrm{a}$ & $0.38 \mathrm{a}$ & 4 & $28 \mathrm{c}$ \\
\hline
\end{tabular}

${ }^{2}$ Plants were planted above grade with PB, PT, CGC mounded on and around the exposed root ball, or planted at soil grade with NOM.

${ }^{y} \mathrm{GI}=$ (height + widest width + width perpendicular to widest width $) \div 3$.

${ }^{x} 1 \mathrm{~kg}=2.2046 \mathrm{lb}$.

w $0=$ no live tissue, $1=1 \%$ to $25 \%$ live tissue, $2=26 \%$ to $50 \%$ live tissue, $3=51 \%$ to $75 \%$ live tissue, $4=76 \%$ to $100 \%$ live tissue but visible stem dieback or leaf spot, $5=100 \%$ live tissue and no visible symptoms of disease or drought. Values reported are the median of six replications.

${ }^{\mathrm{V}} \mathrm{RS}=($ widest width + width perpendicular to widest width $) \div 2 ; 1 \mathrm{~cm}=0.3937$ inch

"Means $(n=6)$ within column and season not significantly different when followed by the same letter, separated using LSD at $P=0.05$.

$12.5 \mathrm{~m}^{2}$, respectively). There were no differences in final SDW among treatments within planting season. Visual ratings of canopies were unaffected by planting season or treatment (Table 1A). Final RS was not different by planting season, but was largest in $\mathrm{PB}$ and $\mathrm{PT}$ regardless of planting season $(P<0.0001)$ (Table 1A). Roots of wax myrtle growing into the soil below the organic matter were thicker and fewer than the many fine roots found in the organic matter layers (visual observation). Tissue micronutrient concentrations at planting were similar for both planting dates, although concentrations decreased from planting to spring sampling in fall-planted shrubs and so in the
Spring 2007, spring-planted shrubs had higher concentrations than did fall-planted shrubs (data not shown).

Mountain Laurel. Survival rate of shrubs was $100 \%$ with the exception of $67 \%$ survival of shrubs planted in the spring above-grade with CGC. Initial GI was similar at planting for fall- and spring-planted shrubs $(P=$ 0.268 ), and at spring planting, shrubs planted in the fall were also similar in size to the spring-planted shrubs $(P=$ $0.4061)$. At experiment termination, GI was higher for shrubs planted in fall $(P=0.0003)$, and there was an interaction of treatment and season $(P=$ 0.0433 ) indicating that those planted in spring in CGC had lower GI than plants in all other treatments (Table 1B). Shoot dry weight at planting was higher $(P=0.0005)$ for spring-planted shrubs $(0.33 \mathrm{~kg})$ than for fall-planted shrubs $(0.29 \mathrm{~kg})$, although by experiment termination, shrubs planted in fall had higher SDW than those planted in spring (Table 1B). Leaf area was similar at planting for spring-planted and fall-planted shrubs $\left(7.4\right.$ and $5.8 \mathrm{~m}^{2}$, respectively). Interactions between season and treatment $(P=0.0475)$ indicated that final SDW of fall-planted shrubs was highest when grown in $\mathrm{PB}$ or PT, while SDW of those planted in spring was highest in $\mathrm{PB}, \mathrm{PT}$, or at grade with NOM. Visual ratings were also lowest for those planted in the spring in CGC (Table 1B). Root spread was affected by both treatment $(P<$ $0.0001)$ and season $(P=0.0062)$, with plants planted in fall and grown with $\mathrm{PB}$ and $\mathrm{PT}$ having the largest root balls at experiment termination (Table 1B). In CGC and NOM, there was very little root growth beyond the original root ball, and in $\mathrm{PB}$ and $\mathrm{PT}$, most root growth was observed in the upper layer of organic matter (visual observation). Tissue nutrient concentrations trends were similar to those found for wax myrtle, and final phosphorus concentrations were highest in shrubs planted above-grade with CGC (data not shown).

Cotton gin compost was the most elementally rich substrate, with the highest concentration of all macronutrients (Table 2). Cotton gin compost also had the highest water holding capacity (69.1\%) and lowest air space (12.4\%) of the organic matter substrates. NOM (native soil) had the highest bulk density $\left(1.5 \mathrm{~g} \cdot \mathrm{cm}^{-3}\right)$, and PB and PT had the lowest (both $0.1-0.2 \mathrm{~g} \cdot \mathrm{cm}^{-3}$ ).

\section{Discussion}

Although fall-planted shrubs of both species were smaller at planting than those planted later in the spring, the fall-planted shrubs were likely able to grow roots during the winter months, and by experiment termination had developed significantly larger canopies than their spring-planted counterparts. The vigorous growth of fall-planted shrubs is also evident in larger RS. These growth parameter results are likely natural outcomes of the fall-planted shrubs simply being in the ground longer than spring-planted shrubs. Previous experiments with mountain laurel suggest that smaller 
Table 2. Concentrations of mineral nutrients, ammonium-nitrogen $\left(\mathrm{NH}_{4}-\mathrm{N}\right)$, and nitrate-nitrogen $\left(\mathrm{NO}_{3}-\mathrm{N}\right)$ of saturated extract of substrates and soil (Marvyn sandy loam).

\begin{tabular}{|c|c|c|c|c|c|c|c|}
\hline Substrate or soil & Calcium & Potassium & Magnesium & Phosphorus & Aluminum & Boron & Zinc \\
\hline Pine bark (PB) & $13.7 b^{y}$ & $64.4 \mathrm{~b}$ & $16.8 \mathrm{~b}$ & $7.4 \mathrm{~b}$ & $26.3 \mathrm{a}$ & $0.3 \mathrm{~b}$ & $0.5 \mathrm{a}$ \\
\hline Peat $(\mathrm{PT})$ & $31.0 \mathrm{~b}$ & $0.6 \mathrm{c}$ & $0.4 \mathrm{~d}$ & $0.2 \mathrm{c}$ & $0.1 \mathrm{~b}$ & $<0.1 \mathrm{c}$ & $0.1 \mathrm{~b}$ \\
\hline \multirow[t]{2}{*}{ Soil } & $1.1 \mathrm{~b}$ & $2.4 \mathrm{c}$ & $2.9 \mathrm{c}$ & $0.2 \mathrm{c}$ & $0.1 \mathrm{~b}$ & $<0.1 \mathrm{c}$ & $<0.1 \mathrm{c}$ \\
\hline & Copper & Iron & Manganese & Sodium & $\mathrm{NH}_{4}-\mathrm{N}$ & $\mathrm{NO}_{3}-\mathrm{N}$ & $\mathrm{pH}$ \\
\hline CGC & 0.2 & $<0.1 \mathrm{c}$ & $<0.1 \mathrm{~b}$ & $3.6 \mathrm{a}$ & $1.1 \mathrm{~b}$ & $518.5 \mathrm{a}$ & $5.7 \mathrm{c}$ \\
\hline Soil & 0.1 & $1.9 \mathrm{a}$ & $<0.1 \mathrm{~b}$ & $3.3 \mathrm{a}$ & $0.1 \mathrm{c}$ & $7.7 \mathrm{~b}$ & $6.9 \mathrm{a}$ \\
\hline
\end{tabular}

${ }^{2}$ Soil and substrate analysis by saturated extraction, Auburn University Soil Testing Laboratory, Auburn, AL; $1 \mathrm{ppm}=1 \mathrm{mg} \cdot \mathrm{L}^{-1}$.

${ }^{y}$ Means $(n=3)$ separated using LSD at $\alpha=0.05$

shrubs may have better post-transplant performance than larger shrubs (Wright et al., 2005); smaller size at planting may have contributed to the success (higher SDW, better survival, larger RS) of the fall-planted shrubs. In addition, spring-planted mountain laurel had lower overall visual ratings than fall-planted shrubs, which may indicate that planting season affects posttransplant success more for this species. Also, treatment differences were more pronounced for spring-planted than fall-planted mountain laurel, suggesting that organic matter selection was particularly important during the first growing season, perhaps because these shrubs were less established than those planted in the fall. Until establishment, the plant has only the transplanted container substrate from which to draw water (Heiskanen and Rikala, 2000), which may be extremely limited due to tendency of surrounding soils to pull moisture from the root ball because of differences in texture and moisture gradients (Costello and Paul, 1975). Research with 'Compactus' burning bush (Euonymus alatus) liners showed that roots growing from lower bulk density substrates, such as the $\mathrm{PB}$ mixes in which many nursery crops are grown, were less likely to penetrate surrounding soil with higher bulk density than roots growing from higher density substrates into similarly highdensity surroundings (Nicolosi and Fretz, 1980). This, combined with the frequent glazing of the planting hole from digging and common tendency of roots of container-grown plants to continue growing in a circle (Ingram and van der Werken, 1978), may effectively inhibit root growth and containerize roots within the original planting hole (Schulte and Whitcomb, 1975). These problems are of particular importance when transplanting plants with high shoot:root ratios while providing little post-transplant care. The inevitable consequence is moisture stress, which can limit photosynthesis. Plant species differ in response to dehydration, but in general water deficit is the most commonly limiting factor to plant growth following transplanting (Kramer, 1983).

Spring-planted shrubs of both species had already allocated much of their resources into new shoot growth before transplanting, and so may not have been able to develop roots into the surrounding soil and grow shoots during the first growing season as rapidly as did those planted in the fall. The time between transplanting and new root growth, as well as the ability of roots to penetrate the surrounding soil, may explain why some containergrown plants are described as easy or difficult to transplant (Harris et al., 1996). Mountain laurel is a member of the family Ericaceae, a feature of which is fine, matted root systems without taproots, often described as hairlike (Leiser, 1968). Container-grown plants with coarser roots of larger diameters like wax myrtle may be able to exert more of the growth pressure necessary to deform soil aggregates than plants with finer roots of smaller diameters like mountain laurel (Clark et al., 2003; Materechera et al., 1992). Container-grown plants with finer roots systems thus may be more difficult to transplant due to slower post-transplant root growth.

The season in which a plant is transplanted may affect the time between transplanting and root growth into the surrounding soil, and ultimately overall success and survival of the plant. The differences between species success by season may be attributed to seasonal potential for root vs. shoot growth, or periodicity. Therefore, the season in which a shrub is planted may be of particular importance, especially for already difficult to transplant species like mountain laurel, which has been shown to allocate resources to root growth in the fall months (Wright et al., 2004) and thus may be more suited to fall planting since plants should be transplanted when root growth rates are highest (Kozlowski and Davies, 1975). Fall planting has been shown to be beneficial for post-transplant shoot growth of many woody species (Harris and Bassuk, 1994; Hinesley, 1986), while spring planting is better for other woody species (Harris and Bassuk, 1994; Larson, 1984).

In general, the planting season and treatment differences were not very pronounced for wax myrtle, considered an easy-to-transplant species. Higher SDW, GI, visual rating, and RS of mountain laurel associated with $\mathrm{PB}$ and PT and the above-grade planting technique, demonstrate that it is of benefit for mountain laurel to be planted using this technique, and $\mathrm{PB}$ or PT is recommended over CGC. Pine bark and PT used with the abovegrade planting technique may contribute to speedier establishment because the layer of organic matter simulates a natural litter layer. These layers of $\mathrm{PB}$ and PT have low-bulk density, making it much easier for roots to penetrate than surrounding soils, particularly under dry conditions in which soils become dry and hard. Once 
established, large, mature roots perform the majority of plant water and nutrient uptake, but thinner, unsuberized new roots absorb water at nearly five times the rate of older roots (Kramer and Bullock, 1966). Thus, speedy fine root proliferation is essential upon transplanting for plants to be able to quickly absorb water and decrease moisture stress, which should aid the growth of more roots that mature and establish the plant into its new surroundings. Plants in cultivation have less than half the root to shoot ratio of those in natural areas (Robinson et al., 2003), possibly because they lack a natural litter layer.

Although it may not be as critical for survival for easy-to-transplant species like wax myrtle, this above-grade planting technique with $\mathrm{PB}$ or $\mathrm{PT}$ was still beneficial and was in no way detrimental. Although wax myrtle had a $100 \%$ survival rate, mountain laurel planted in the spring with CGC had only a $67 \%$ survival rate. CGC, like many composts, has high electrical conductivity and nitrate $\left(\mathrm{NO}_{3}\right)$, and salts, particularly sodium $(\mathrm{Na})$ and potassium (K) (data not shown). Species with fine root systems like mountain laurel may be particularly vulnerable to these high salt levels (Sxbø and Ferrini, 2006), and therefore, CGC is not recommended for general use with any shrub species. Composts like CGC should only be used in urban areas when heavily diluted in mixes with soil or other organic matter (Sæbø and Ferrini, 2006).

Although data were collected only during the first growing season, this field experiment comparing two native species demonstrates the benefit in the first growing season following transplanting of using this above-grade planting technique with $\mathrm{PB}$ or PT. This technique could also likely be used in other regions to encourage posttransplant root growth of shrubs, although planting dates should coincide with region-specific growing seasons. The results show that this method could be used when transplanting native shrub species from diverse habitats to encourage post-transplant root and shoot growth and contribute to establishment of the shrubs to develop attractive, low-maintenance landscapes.

\section{Literature cited}

Arnold, M.A., G.V. McDonald, and D.L. Bryan. 2005. Planting depth and mulch thickness affect establishment of green ash and bougainvillea raintree. J. Arboriculture 31:163-167.

Clark, L.J., W.R. Whalley, and P.B. Barraclough. 2003. How do roots penetrate soil? Plant Soil 255:93-104.

Costello, L. and J.L. Paul. 1975. Moisture relations in transplanted container plants. HortScience 10:371-372.

Day, S.D., N.L. Bassuk, and H. van Es. 1995. Effects of four compaction remediation methods for landscape trees on soil aeration, mechanical impedance, and tree establishment. J. Environ. Hort. 13:64-71.

Dirr, M.A. 1998. Manual of woody landscape plants, 5th ed. Stipes Publishing, Champaign, IL.

Fonteno, W.C., D.K. Cassel, and R.A. Larson. 1981. Physical properties of three container media and their effect on poinsettia growth. J. Amer. Soc. Hort. Sci. 106:736-741.

Harris, J.R. and N.L. Bassuk. 1994. Seasonal effects on transplantability of scarlet oak, green ash, turkish hazelnut and tree lilac. J. Arboriculture 20:310-317.

Harris, R.W., P. Knight, and J. Fanelli. 1996. Fall transplanting improves establishment of balled and burlapped fringe tree (Chionanthus virginicus L.). HortScience 31:1143-1145.

Heiskanen, J. and R. Rikala. 2000. Effect of peat-based container media on establishment of scots pine, norway spruce, and silver birch seedlings after transplanting in contrasting water conditions. Scandinavian J. Environ. For. Res. 15:49-57.

Hinesley, L.E. 1986. Effect of transplanting time on growth and development of fraser fir seedlings. HortScience 21:65-66.

Ingram, D.L. and H. van der Werken. 1978. Effects of container media and backfill composition on the establishment of container-grown plants in the landscape. HortScience 13:583-584.

Kozlowski, T.T. and W.J. Davies. 1975. Control of water balance in transplanted trees. J. Arboriculture 1:1-10.

Kramer, P.J. 1983. Water relations of plants. Academic Press, New York.

Kramer, P.J. and H.C. Bullock. 1966. Seasonal variations in the proportions of suberized and unsuberized roots of trees in relation to the absorption of water. Amer. J. Bot. 53:200-204.

Larson, M.M. 1984. Seasonal planting, root regeneration and water deficits of austrian pine and arborvitae. J. Environ. Hort. 2:33-38.

Leiser, A. 1968. A mucilaginous root sheath in Ericaceae. Amer. J. Bot. 55: 391-398.

Materechera, S.A., A.M. Alston, J.M. Kirby, and A.R. Dexter. 1992. Influence of root diameter on the penetration of seminal roots into a compacted subsoil. Plant Soil 144:297-303.

Nicolosi, R.T. and T.A. Fretz. 1980. Evaluation of root growth in varying medium densities and through dissimilar soil surfaces. HortScience 15:642-644.

Robinson, D., A. Hodge, and A. Fitter. 2003. Constraints on the form and function of root systems, p. 1-31. In: H. de Kroon and E.J.W. Visser (eds.). Root ecology. Springer-Verlag, Berlin.

Sæbø, A. and F. Ferrini. 2006. The use of composts in urban green areas-A review for practical application. Urban For. Urban Gardening 4:159-169.

Schulte, J.R. and C.E. Whitcomb. 1975. Effects of soil amendments and fertilizer levels on the establishment of silver maples. J. Arboriculture 1:192-195.

Southeast Exotic Pest Plants Council. n.d. Landscaping with Native Plants. 6 June 2011. <http://www.se-eppc.org/pubs/ landscape.html>.

U.S. Department of Agriculture. 1997. Official Soil Series Descriptions. 8 Jan. 2008. <http://ortho.ftw.nrcs.usda.gov/ osd/dat/M/MARVYN.html>.

Wright, A.N., S.L. Warren, F.A. Blazich, and U. Blum. 2004. Root and shoot growth periodicity of Kalmia latifolia 'Sarah' and Ilex crenata 'Compacta'. HortScience 39:243-247.

Wright, A.N., S.L. Warren, F.A. Blazich, J.R. Harris, and R.D. Wright. 2005. Initial plant size and landscape exposure affect establishment of transplanted Kalmia latifolia 'Olympic Wedding.'. J. Environ. Hort. 23:91-96.

Wright, A.N., R.D. Wright, B.E. Jackson, and J.F. Browder. 2007. Effect of backfill composition on post-transplant root growth of Kalmia latifolia L. J. Environ. Hort. 25:145-149. 